\title{
Third-Party Payments Impact on Commercial Banks’ Non-Interest Income: Evidence from China
}

\author{
Huiwen $\mathrm{Xia}^{1} \&$ Nada Chunsom ${ }^{1}$ \\ ${ }^{1}$ Graduate School of Development Economics, National Institute of Development Administration (NIDA), \\ Bangkok, Thailand \\ Correspondence: Huiwen Xia, Graduate School of Development Economics, National Institute of Development \\ Administration (NIDA), Bangkok, Thailand. Tel: 66-090-257-8819. E-mail: 1092803573@qq.com
}

Received: June 22, 2018

doi:10.5539/ijef.v10n8p190
Accepted: July 17, 2018

Online Published: July 25, 2018

URL: https://doi.org/10.5539/ijef.v10n8p190

\begin{abstract}
This study aims to explore the effects of Chinese third-party payments on commercial banks' non-interest income over the period 2008-2017. In China, third-party payment is a digital payment provided by private non-bank firms that consist of desktop payment and mobile payment. More people prefer to use third-party payment, especially the mobile payment, instead of cash and bank card as the payment can be transacted easily and safely on the mobile phone by scanning QR code. To find whether this new digital payment trend impacts on commercial banks' non-interest income or not, this paper first employs the random effects panel data technique. The regression results show that for overall banks, higher desktop payment yields higher non-interest income, while the mobile payment deters the non-interest income. Then in order to investigate whether third-party payment exerts the effects differently across bank types, we include interaction terms and dummy variables in the regression. Findings show that from the perspective of bank types, small-medium commercial banks reap the positive spillover effects. But for large state-owned commercial banks, the non-interest income suffers a loss when desktop payment and mobile payment are growing. Based on the findings, the insightful policy implications are put forth for commercial banks' non-interest income expansion and profitability enhancement.
\end{abstract}

Keywords: digital payment, mobile payment, non-interest income, random effects model, interaction terms

\section{Introduction}

Initiating from the digital age, the Chinese payment market has undergone the remarkable reforms in recent years. These reforms gradually promoted the payment patterns to be more efficient, convenient, and secure, particularly on the Internet finance and e-commerce market. Third-party payment, with the typical features of fast speed, low cost, and the high security, is spurting and spreading with giant strides in China. Compared with the traditional bank payment, third-party payment is accomplished in non-bank firms via digital process and procedures, mainly in the term of desktop payment and mobile payment. So far, a large number of descriptive studies analyze the impacts of third-party payment on bank performance (Shuo \& Ting, 2012; Junping, 2012; Hua \& Juanjuan, 2017; Diwanji \& Kannan, 2017), a few studies related to the empirical evidence (Man, 2015). In the perspective of third-party desktop payment and mobile payment, empirical study relates to commercial bank's non-interest income is rather rare.

The interest in this topic is motivated by two factors. The first derives from the experiencing of real life, as well as the discovering in payment literature. The innovative digital payment patterns like third-party desktop payment, mobile payment have increasingly attracted attention and application all over the world. Globally well-known third-party payment companies are the United States PayPal (1998), British Skrill (2001), China Alipay (2004), Germany Giropay (2006), Japan Line pay (2014). Among them, PayPal was established in 1998, is one of the first companies engaged in person to person online payment (D. Williams, 2007). The founder of PayPal, Thiel, has stated that PayPal is an Internet payment company but not a bank because PayPal does not carry out fractional-reserve banking (Thiel \& Levchin, 2004). This is consistent with the concept of third-party payment in China. And a study from Manning (2015) shows that as the third-party payment providers in the U.S. like PayPal, Apple and Google are constructing a direct relationship with customers over convenient, bank's business may get challenged with the expanding of the digital payment in third-party companies.

Considering the Chinese market, third-party payment is being piloted by Alipay and WeChat pay. Alipay 
introduced desktop payment in 2004 and it has been developing stably since then. Based on the Alibaba e-commerce platform, Alipay grows rapidly and rationally in both desktop payment and mobile payment. Right after the Alipay third-party payment, WeChat payment became the second largest platform, relying on its huge social communication system, it also quickly opens online payment in the mobile market in 2013 (Yixian, 2017). Developed till present, desktop payment has a relatively long time period and a stable growth rate, while mobile payment rises rather sharply. The research from Goldman Sachs (Mancy, Piyush, Tian, \& Stanley, 2017) found that the number of electronic payment transactions via third-party payment is greater than transactions via banks. But the average amount per transaction of third-party payment is much lower than banks. It indicates that the dominant payment still lies on banks, but in terms of transaction frequency, third-party payment has higher potential velocity as more and more people shift to use it. Directly and indirectly, third-party payment is reshaping bank' non-interest income. Therefore, our first motivation is to explore: what is the impact of third-party total payment on the commercial bank's non-interest income? Specifically, what are the impacts of third-party desktop payment and mobile payment on commercial bank's non-interest income?

The second motivation arises from the research on the importance of non-interest income and the difference in bank types. Research in European countries found that the profitability of the commercial banking business, such as commercial loans and deposits, has declined in recent years. Hence, banks have turned to expand product breadth and to improve non-interest income (Smith, Staikouras, \& Wood, 2003). In India, the empirical evidence results (Mostak Ahamed, 2017) elaborate that as banks move away from interest income toward non-interest income banking businesses, they earn higher profits and risk-adjusted profits. To testify whether non-interest income affects commercial banks financial performance in the United States, DeYoung and Rice (2004) findings suggest that noninterest income and interest income are coexisting rather than replacing. From 1980 to 2002, the U.S. banking rate of non-interest income on aggregate operating income increased more than doubled, from $20 \%$ to $42 \%$. It becomes more obvious that nowadays intermediation business remains to play the core financial services role of commercial banks. In China, commercial banks gradually adjust income structure to raise the proportion of non-interest income after implementation of the modern corporate governance pattern in this transitional period. External pressure and internal motivation are dual prime powers that push China commercial banks to pay more efforts to promote non-interest income growth $(\mathrm{Li}, 2014)$. The stringent supervision is the major external pressure, especially for capital adequacy requirements. Compared with interest business, non-traditional business generating non-interest income expends less economic capital. Hence, commercial banks inevitably turn to pay more attention to non-interest income business under capital constraints. Meanwhile, the accelerated liberalization of interest rate and the intensification of homogeneity competition lead to narrow interest spread. Since the potential benefit spaces of non-interest business still can be developed, there are strong internal incentives for commercial banks to extend non-interest businesses.

Most of the studies state that government ownership of large bank does not tend to have better efficiency or profitability (e.g. Pennathur et al., 2012; Altunbas et al., 2001; Beck, Demirgüç-kunt, \& Maksimovic, 2003). As the transformation of China's economy and society has profoundly promoted the evolution of the banking system towards to marketization since 1979, the banking layout in China has undergone cracking changes. In essence, it has shifted from a planned dominant economy structure to a pluralistic system containing diverse of market-oriented banks (Xu, Rixtel, \& Leuvensteijn, 2013). The research from Elliott and Yan (2013) summarize that the banking industry in China is highly centralized, top five largest state-owned commercial banks control about half of the entire banking assets. Followed by joint-equity commercial banks and city commercial banks, which can be referred to the small and medium size group. Thus, from different bank types perspective, the second motivation of this paper is to explore: what the different impacts of third-party payment on non-interest income between large state-owned banks and small-medium banks in China?

Overall, the objective of our study is twofold. First, we discuss the determinants of non-interest income and specify the panel data random effects model, so as to explore the impacts of third-party total payment, desktop payment and mobile payment on commercial bank's non-interest income. Second, the interaction terms approach is involved in the regression to examine whether this impact differs across large commercial banks and small-medium commercial banks.

The rest of the paper is structured as follows: Section 2 discusses the existing literature. The data description and empirical models are presented in section 3. Section 4 reports the regression results and discussions, while section 5 concludes the paper and provides some policy implications. 


\section{Review of Literature}

\subsection{Digital Payment and Bank's Non-Interest Income}

The fast growth of digital payment via non-bank providers (third-party payment companies) is an issue of great concern in many countries. Both the research from Germany (Thomas, 2014) and the U.S. (Tandulwadikar, 2015) reckon that we still remain at a relatively early stage of digital payment society that urgently requires further potential academic research. The prior research regarding digital payment is mainly from the developed countries, such as the U.S., the UK, Germany, and the emerging economies like India and China. Most theoretical studies document that digital payment brings the challenges for banks. For example, Denecker, Gulati, and Niederkorn (2014) deem that payment represents the gateway for the entire banking activities, and through analyzing the digital payment situations in the United States, they further found that digital payment in non-bank competitors has higher operational productivity. This brings bank's non-interest income under attack. Similarly, a report from Tandulwadikar (2015) suggests that the U.S. retail banks need to provide strong payment patterns and embrace mobile payment approach in order to compete with non-bank digital payment companies. In the UK, Robleh et al. (2014) describe that the innovative third-party digital payment distributes the bank's non-interest income flow. Same findings as Robleh et al. (2014), by detecting the development of digital payment in Germany, Thomas (2014) discovers that the third-party digital payment is squeezing the scale on banking sectors. As traditional banks have individual digital shortcomings, Fintech companies are increasingly gaining the payment market share, replacing some non-interest income activities of banks. For emerging economies like India, the research from Wahi (2017), Diwanji and Kannan (2017) shows that the digital payment has grown quite quick no matter in terms of transactions or values, and mobile wallet is expected to grow in popularity due to the convenience. As a result, the new trend of the digital payment intensifies the competition from the bank's credit and debit card businesses.

In China, although commercial banks play an important role in domestic financial markets, in the initial stages of online shopping development, commercial banks do not adapt to changes in transaction patterns and payment methods. Fuchun (2010) and Kun (2010) summarize that the advent of the third-party payment platform successfully solved the trust problems between sellers and buyers for the time-space separation between the delivery of the online transaction and the payment of funds. Since then, the third-party payment platform for desktop payment and mobile payment have been booming. Referring to the literature, most of the third-party payment research has been carried out by the qualitative method. Empirical studies mainly emphasized the impact of Internet finance on bank performance. Internet finance consists of third-party payment service, Peer to Peer lending \& borrowing, crowdfunding \& investment and other Internet forms (Man, 2015). From the Internet finance perspective, most studies show that Internet finance has a positive effect on bank performance, such as the research of Guo and Shen (2016), studying the effects by using the dynamic panel model and SYS-GMM test for thirty-six China commercial banks during period 2003-2013. And the research from Peijun (2014) for 16 Chinese banks from 2002 to 2013.

However, the majority of studies claim that third-party payment presents the negatively impact on bank performance. Using the 16 Chinese banks as a sample, Man (2015) employs panel data model to run the regression, with the results showing that, to a certain extent, the third-party payment reduces the operating efficiency of commercial banks through decreasing the intermediary business income and profitability. Hua and Juanjuan (2017), by analysis the competition and cooperation correlation between third-party payment institutions and commercial banks, summarize that third-party payment seems to reduce the bank profit.

\subsection{The Determinants of Non-Interest Income}

Besides third-party payment factor, we need to find other determinants of non-interest income as the control variables. According to the existing literature, many factors associated with the economies may affect the non-interest income of commercial banks. It could depend on the supervision of the government on the banking industry, and the degree of financial market development, as well as the commercial bank's own development strategy and management level. Some theoretical and empirical studies showed that determinants of non-interest income mainly stand on banking characteristics and macro factors.

\section{(1) Banking Characteristics}

Size: The size of the bank is often considered as one of the crucial factors which can influence the non-interest income. In America, Pelton (1960) selected 1508 American banks as a sample to examine the determinants of the non-interest income during 1988-2008. He found that bank size in terms of total assets is positively correlated with the ratio of non-interest income to total assets. But total assets growth was considered ambiguous on how it would contribute to non-interest income to total asset ratio. Similarly, DeYoung and Hunter (2002) also prove that the 
size of the bank possesses a positive relationship with non-interest income.

Net interest margin: It reflects banks profitability based on interest income business. Joon-Ho Hahm (2008) studied 29 OECD countries (the Organization for Economic Co-operation and Development) with the sample of 662 commercial banks. The results showed that banks with low net interest margins would cause higher non-interest income. Same conclusions are drawn as Joon-Ho, by observing 10 Tunisian deposit banks from 1998 to 2009, Abdelaziz et al. (2012) find that the net interest margin is negatively and significantly correlated with non-interest income. In the case of European, Smith et al. (2003) analyzed European countries banking industry during 1994-1998. Both the time series analysis and cross-section analysis were used to examine the diversification and variability of non-interest income. Their findings suggested that, in several European countries, a negative correlation appears to exist between interest income and non-interest income, and also suggest that the reduction in the net interest margin may not be amply offset for the augment of non-interest income.

Loan-deposit rate: To pursue more profits, large size banks tend to set a considerable high loan-deposit ratio which drives large banks to develop non-interest income to diversify the potential risks. So, it's a positive relationship (Shujin \& Yinfei, 2016). On the contrary, DeYoung and Rice (2004) found that non-interest income would increase when banks' strategy is to diversify its incomes, suggesting a negative correlation between the loans ratio and the amount of non-interest income raised by commercial banks. In addition, an empirical study from China (Junshan \& Guoqiang, 2011) presents that non-interest income is not significantly linked to the loan-deposit ratio of commercial banks.

Overhead ratio: Based on Davis and Tuori (1998) study in the 28 OECD countries banking sector for 1979-1995, it was concluded that less cost-effective banks like small banks tend to have a higher overhead ratio. For such small banks, there may be incentives to diversify the revenue sources by expanding non-interest income, so that they can preserve profitability. With similar results to DeYoung \& Hunter (2002), the positive correlation was discovered between non-interest income and overhead ratio in the U.S. commercial banking sector. However, the study from Karakaya \& Er (2012) on the Turkish banking industry yields different outcomes. The conclusion conducts that bank's financial performance is negatively affected by overhead ratio. As efficient banks with good performance are expected to have relatively lower operating costs.

\section{(2) Macro Factors}

The macroeconomic factors that affect non-interest income from previous studies mainly include two broad types, GDP growth rate, and inflation rate.

GDP growth rate: Both Joon-Ho Hahm (2008) and Atellu (2016) conclude that the country with the rapid GDP growth rate seems to have a lower non-interest income rate. This negative correlation suggests that as economic boosts, people will increase the investment due to their optimistic perceptions of the economy. The increasing demand for lending promotes banks lending and borrowing business income. Thus banks focus more on interest income and have less incentive to diversify to non-interest income. For Abdelaziz et al. (2012), there is no significant effect of economic growth on the degree of non-interest income in their empirical results.

Inflation rate: By using the data of 10 Tunisian banks from 1998 to 2009, Abdelaziz et al. (2012) found that inflation rate poses a negative effect on non-interest income. And this effect is very significant. The significantly negative coefficient of inflation rate also observed by Joon-Ho Hahm (2008) in OECD countries banking.

Payment policy: Most research study the determinants and non-interest income includes the policy factor, but usually in terms of deregulation. To some extent, deregulation policy on bank industry has changed the market structure, which in turn affects banks performance. But for non-interest income, it has an insignificantly positive relationship associated with deregulation in Kenya Atellu (2016). Same findings as Atellu, Craigwell, and Maxwell (2006) showed that deregulation does not act as a determining role of non-interest income in Barbados. As deregulation directly affects market competition through banks deposits and loans, the effects on the growth of non-interest income have not been reflected. In China, there some deregulation policies relate to third-party payment, such as the Barcode Payment Business Norms in 2016 issued by Payment and Clearing Association of China. The policy strengthened the payment security and boosted the mobile payment in 2016. Hence, our paper would incorporate this payment policy to investigate the impact on bank' non-interest income. Set payment policy as a dummy variable, it equals 1 when the payment policy is implemented in that year. Otherwise, it equals 0 .

\subsection{Theoretical Model}

In accordance with the theory of income diversification and portfolio (Markowitz, 1959; Calomiris, 1998; Stiroh, 2004), diversification of non-interest business may allow for increasing the expected return at the same risk level. Commercial banks' non-interest income diversification can be carried out with a variety of strategies. Atellu 
(2016) explores the variables that primarily influence diversification in portfolios of non-interest income. The variables include deregulation, bank-specific characteristics, technological development and macroeconomic factors. Combining the set of multi-factors, it is, in turn, related linearly to the non-interest income based on the Arbitrage Pricing Theory from Ross (1976).

Apart from banking characteristics and macro factors, third-party payment could play a key role in non-interest income activities. According to financial innovation theory (Frame \& White, 2004), the third-party payment platform is one of the innovative financial intermediation which serves as digital money. Thus, Junping (2012) and Wenqing (2015) conclude that the impact of third-party payment innovation on a commercial bank's non-interest income may be through these three channels: (1) Technical process innovation makes payment ease and instant; (2) Business model innovation solves the problem of trust in online shopping; (3) User experience innovation induces mobile payment efficiency and personalization.

The physical connection between third-party payment platforms and commercial banks is that each third-party payment user needs access to the bank card for the first-time flow money into the platform. Therefore, we shall develop our hypothesis that third-party total payment will exert a positive effect on commercial bank' non-interest income, while there is a negative relationship between third-party mobile payment and non-interest income.

\section{Methodology}

\subsection{Data and Sample Selection}

The data collection mainly comes from three categories. One category is third-party payment data in which third-party desktop payment covers the period 2008-2017. Third-party mobile payment covers the period 2013-2017, encompassing the experience of Chinese third-party payment development. This categorical data is obtained from China iResearch third-party payment reports. The macro factor is the second category. Both GDP and Inflation rate can be gathered from China Statistical Yearbook. The third category is banking industry data which is mainly collected from the Bankscope database and bank's annual reports. Most information can be directly gathered, such as non-interest income, total assets, total loans, total deposits, net interest margin, return on assets, overhead ratio, and non-performing loan. For the sake of the usefulness, we calculate two ratios, i.e. non-interest income to total assets ratios and deposit-loan ratios. The sample includes 16 listed banks operating in China banking industry throughout 2008-2017, of which 5 are large state-owned commercial banks, 8 are joint-equity commercial banks, and 3 are city commercial banks. These 16 listed banks' total assets account for the entire of China commercial banks more than $80 \%$ of total assets (Elliott \& Yan, 2013).

Table 1 displays the definitions of variables as well as some general statistics of the data for all sample banks. The non-interest income rate (NIT) varies between 0.026 and 1.33 with an average of 0.39 . This value is relatively small because the amount of non-interest income is tiny and trivial compared with the commercial banks' tremendous total assets. The natural logarithm of third-party total payment (LNTPP) ranges from 24.6 to 31.4 , with a mean of 27.9 and a standard deviation of 2.0. Table 2 shows the descriptive statistics by bank types for the period 2008-2017. In general, the five state-owned commercial banks have the largest scales of total assets, followed by joint-equity commercial banks and city commercial banks. And the non-interest income also indicates the same tendency. For large state-owned commercial banks, non-interest income comprises $0.46 \%$ of the total assets, while the ratio for city commercial banks is nearly half of state-owned commercial banks. Moreover, the risk of state-owned commercial banks ranks higher than joint-equity commercial banks and city commercial banks with respect to the non-performing loan. 
Table 1. Descriptive statistics of all banks

\begin{tabular}{ccccccc}
\hline \multicolumn{2}{c}{ All banks } & & & & \\
\hline Variable & Definitions & Obs & Mean & Std.Dev. & Min & Max \\
\hline NIIT & Non-interest income/Total assets & 620 & 0.394307 & 0.24078 & 0.02644 & 1.33071 \\
LNTA & The natural logarithm of total assets & 620 & 28.68547 & 1.27917 & 25.1371 & 30.8925 \\
LDR & Loan/Deposit & 598 & 71.80996 & 8.98356 & 42.681 & 102.17 \\
NIM & Net interest income/Average interest-bearing assets & 624 & 2.529776 & 0.39394 & 1.4 & 3.66 \\
ROA & Earnings before tax/Average gross assets & 626 & 0.732099 & 0.33388 & 0.0943 & 1.7154 \\
OVHR & Cost/Income & 626 & 29.90056 & 5.94377 & 15.6 & 46.9607 \\
NPL & Bad loans/Loans & 607 & 1.170692 & 0.54058 & 0.34 & 5.15 \\
GDP & The growth rate of GDP & 640 & 8.345 & 1.65749 & 6.4 & 12.2 \\
INFL & Represented by the Consumer Price Index & 640 & 2.577 & 2.00964 & -1.7 & 8.3 \\
POL & Payment policy, Yes=1; Otherwise=0 & 640 & 0.189063 & 0.39186 & 0 & 1 \\
LNTPDP & The natural logarithm of third-party desktop payment & 640 & 27.49295 & 1.50785 & 24.6089 & 29.6812 \\
LNTPMP & The natural logarithm of third-party mobile payment & 320 & 28.77743 & 1.88427 & 24.4747 & 31.2614 \\
LNTPP & The natural logarithm of third-party total payment & 640 & 27.93268 & 2.01544 & 24.6089 & 31.4487 \\
\hline
\end{tabular}

Table 2. Descriptive statistics by bank types

\begin{tabular}{lcccccccccccc}
\hline Types & \multicolumn{3}{c}{ State-owned banks (Obs.=193) } & \multicolumn{3}{c}{ Joint-equity banks (Obs.=313) } & \multicolumn{4}{c}{ City banks (Obs.=120) } \\
\hline Variable & Mean & Std.Dev. & Min & Max & Mean & Std.Dev. & Min & Max & Mean & Std.Dev. & Min & Max \\
\hline NIIT & 0.46 & 0.21 & 0.071 & 0.978 & 0.403 & 0.267 & 0.045 & 1.331 & 0.265 & 0.15 & 0.0264 & 0.865 \\
LNTA & 30.07 & 0.544 & 28.447 & 30.892 & 28.485 & 0.633 & 26.738 & 29.488 & 26.939 & 0.869 & 25.137 & 28.453 \\
LDR & 70.15 & 8.476 & 50.844 & 90.685 & 75.745 & 6.655 & 62.179 & 102.17 & 63.480 & 9.092 & 42.681 & 84.898 \\
NIM & 2.461 & 0.359 & 1.57 & 3.56 & 2.555 & 0.4 & 1.4 & 3.66 & 2.575 & 0.419 & 1.83 & 3.544 \\
ROA & 0.788 & 0.338 & 0.227 & 1.475 & 0.685 & 0.325 & 0.094 & 1.46 & 0.764 & 0.335 & 0.227 & 1.715 \\
OVHR & 28.39 & 4.351 & 19.32 & 44.71 & 31.598 & 6.18 & 18.03 & 46.961 & 27.899 & 6.288 & 15.6 & 46.87 \\
NPL & 1.445 & 0.502 & 0.81 & 4.32 & 1.107 & 0.565 & 0.34 & 5.15 & 0.865 & 0.231 & 0.35 & 1.74 \\
GDP & 8.345 & 1.66 & 6.4 & 12.2 & 8.345 & 1.659 & 6.4 & 12.2 & 8.345 & 1.663 & 6.4 & 12.2 \\
INFL & 2.577 & 2.013 & -1.7 & 8.3 & 2.577 & 2.011 & -1.7 & 8.3 & 2.577 & 2.016 & -1.7 & 8.3 \\
POL & 0.2 & 0.401 & 0 & 1 & 0.178 & 0.383 & 0 & 1 & 0.2 & 0.402 & 0 & 1 \\
LNTPDP & 27.49 & 1.51 & 24.609 & 29.681 & 27.493 & 1.509 & 24.609 & 29.681 & 27.493 & 1.513 & 24.609 & 29.681 \\
LNTPMP & 28.78 & 1.891 & 24.475 & 31.261 & 28.777 & 1.887 & 24.475 & 31.261 & 28.777 & 1.897 & 24.475 & 31.261 \\
LNTPP & 27.93 & 2.019 & 24.609 & 31.449 & 27.933 & 2.017 & 24.609 & 31.449 & 27.933 & 2.022 & 24.609 & 31.449 \\
\hline
\end{tabular}

\subsection{Analytical Method}

Panel data is used in this study as our data contains time series observations $(\mathrm{T})$ and a number of individuals $(\mathrm{N})$. There are usually three models for panel data estimation, namely pooled model, fixed effects model, and the random effects model. To decide which model is more appropriate, we can check the F test and the Hausman (1978) test. The test results show that the random effects model is appropriate for our data as the individual error term is not correlated with the explanatory variables. So, using the random effects model had an advantage on including invariant variables. But for the fixed effects model, these variables are absorbed by the intercept.

In terms of the variables, since commercial banks' non-interest income is diversified, this study first focuses on finding the determinants. Following DeYoung and Rice (2004), Njogu (2014) and Abdelaziz, Helmi, and Mouldi (2012), we employ the multiple linear panel data random effects model as follows:

$\mathrm{NIIT}=\mathrm{f}\{$ banking characteristics, macro factors, third-party payment $\}$

$$
N I I T_{i t}=\beta_{0}+\sum_{k} \beta_{k} X_{i t}^{k}+\sum_{n} \beta_{n} Z_{i t}^{n}+\beta_{1} P_{i t}+\varepsilon_{i t}
$$

Where NIIT $_{\text {it }}$ is the ratio of non-interest income to total assets for bank i and in year t. $X_{\text {it }}$ refers to a vector of bank characteristics variables, and $Z_{i t}$ refers to a vector of macro factors, with parameters $n$ to be estimated. The $\mathrm{P}_{\mathrm{it}}$ is either third-party total payment or third-party desktop payment or third-party mobile payment.

By including all the independent variables in the Eq.(1), we can construct our empirical model, using a translog functional form (Diewert \& Wales, 1987).

$$
\begin{gathered}
N I I T_{i t}=\beta_{0}+\beta_{1} L N T A_{i t}+\beta_{2} L D R_{i t}+ \\
\beta_{3} N I M_{i t}+\beta_{4} R O A_{i t}+\beta_{5} O V H R_{i t}+\beta_{6} N P L_{i t}+\beta_{7} P O L+\beta_{8} G D P_{t}+ \\
\beta_{9} I F L_{t}+\beta_{10} L N T P P_{t}+\varepsilon_{i t}
\end{gathered}
$$


Among banking characteristics, total assets $\left(\mathrm{LNTA}_{\mathrm{it}}\right)$ measures the size of banks. The proxies of the loan to deposit ratio $\left(\mathrm{LDR}_{\mathrm{it}}\right)$ and the overhead ratio $\left(\mathrm{OVHR}_{\mathrm{it}}\right)$ represent the operational efficiency. Net interest margin $\left(\mathrm{NIM}_{\mathrm{it}}\right)$ and returns to assets $\left(\mathrm{ROA}_{\mathrm{it}}\right)$ are bank's performance variables to characterize the profitability of interest income business and the profitability of overall business (Pennathur et al., 2012). Non-performing loan ratio $\left(\mathrm{NPL}_{\mathrm{it}}\right)$ reveals the risks and assets quality. Regarding the fluctuation of the macro environment, the factors of GDP, inflation rate, and payment policy are taken into consideration. The key variable, third-party total payment scale $\left(\mathrm{LNTPP}_{\mathrm{t}}\right)$, is also contained in the above equation. The effects of third-party payment and third-party mobile payment can be estimated by replacing $\mathrm{LNTPP}_{t}$ with $\mathrm{LNTPDP}_{t}$ and $\mathrm{LNTPMP}_{\mathrm{t}}$ in the regression.

Secondly, in order to investigate whether third-party payment exerts the effects differently across bank types, we include interaction terms and dummy variables in the regression. Follow the research of M.Wooldrige (2011) and Williams and Dame (2015), we can capture the difference between the two groups in one model by involving the dummy variable. In this case, it assumes that each the independent variable has the same effect or slope for both groups, and the difference lies in the intercept. Furthermore, if the model allows all coefficients freely differ across the groups, more specific differences can be detected by adding the interaction terms (Zhao, Casu, \& Ferrari, 2010). With respect to our sample, the 16 Chinese commercial banks can be divided into two groups. One group is the five largest commercial banks, another group is eight joint-equity commercial banks plus three city commercial banks. Since the main differences between the two groups are the ownership and bank size, we can create the size dummy variable to form the interaction terms as:

$$
\begin{aligned}
I_{i t}= & \delta_{0}+\delta_{1} D_{s}+\delta_{2} \mathrm{LNTA}_{\mathrm{it}} \times D_{s}+\delta_{3} \mathrm{LDR}_{\mathrm{it}} \times D_{s}+\delta_{4} \mathrm{NIM}_{\mathrm{it}} \times D_{s}+\delta_{5} R O A_{\mathrm{it}} \times D_{s}+\delta_{6} O V H R_{i t} \times D_{s}+ \\
& \delta_{7} \mathrm{NPL}_{\mathrm{it}} \times D_{s}+\delta_{9} P O L \times D_{s}+\delta_{10} G D P_{t} \times D_{s}+\delta_{11} I F L_{t} \times D_{s}+\delta_{8} L N T T P_{t} \times D_{s}+v_{i t}
\end{aligned}
$$

Eq. (3) incorporates 10 independent variables to reflect the interactive effect of bank size. $D_{s}$ denotes the size dummy variable. Set $D_{s}=1$ if it is the five largest state-owned banks group, otherwise $D_{s}=0$. Each interactive term facilitates estimator difference between two group banks. Therefore, coming to the empirical model of Eq. (2), the model involving the interaction terms is fully specified as:

$$
\begin{aligned}
\text { NIIT }_{i t}=\beta_{0} & +\beta_{1} \text { LNTA }_{\text {it }}+\beta_{2} \mathrm{LDR}_{\mathrm{it}}+\beta_{3} \mathrm{NIM}_{\mathrm{it}}+\beta_{4} R O A_{\mathrm{it}}+\beta_{5} O V H R_{i t}+\beta_{6} \mathrm{NPL}_{\mathrm{it}} \\
& +\beta_{7} P O L+\beta_{8} G D P_{t}+\beta_{9} I F L_{t}+\beta_{10} L N T T P_{t}+\varepsilon_{\mathrm{it}}+I_{i t}
\end{aligned}
$$

For each explanatory variable, $\beta$ explicates the effects for small-medium banks, and the corresponding $\beta+\delta$ characterized the effects for large state-owned banks. Again, the effects of third-party payment and third-party mobile payment can be estimated by replacing $\mathrm{LNTPP}_{t}$ with $\mathrm{LNTPDP}_{t}$ and $\mathrm{LNTPMP}_{t}$ in the regression.

\section{Results and Discussions}

This section first presents empirical results to find the determinants of commercial banks' non-interest income, and particularly to explore the effect of third-party payment on commercial banks' non-interest income. Then from two groups of banks perspective, this section explores whether this relationship between third-party payment and commercial banks' non-interest income differs across the five largest state-owned commercial banks and small-medium commercial banks.

The regression results for Eq. (2) are reported in Table 3. While column 1 reports the determinants of commercial banks' non-interest income, the effects of third-party desktop payment and third-party mobile payment on commercial banks' non-interest income are reported in column 2. In terms of econometric issues, the data used in this study covers 40 quarterly periods, so it is necessary to check whether all the variables are stationary or not before starting panel data analysis. By using Augmented (ADF) Dickey-Fuller unit root test, the results show that all the variables are stationary at first differencing. Then random effects panel data technique is employed after checking the Hausman test.

For the first column in Table 3, the results show that most variables significantly determined non-interest income. Especially for banking characteristics, total assets, loan to deposit ratio, return on assets and non-performing loan ratio all exert the significant positive effects upon non-interest income. This results present that larger assets banks are more likely to realize economies of scale and achieve more non-interest income, in line with the studies in American from Pelton (1960), DeYoung and Hunter (2002). The banks perform well with higher ROA tend to generate more non-interest- income. Same as Yuhua and Xiaodong (2014) noted, better performance banks would like to diversify the income sources. Both loan to deposit ratio and non-performing loan ratio are the risk measurements of traditional interest-based businesses. With higher liquidity risk or bad debt risk, banks are forced to expand the non-interest income activities to offset the risks (Shujin \& Yinfei, 2016). While only net interest margin shows the significantly negative correlations with non-interest income. If banks focus on the interest income activities would have higher profitability, there is less incentive to diversify the non-interest 
income activities. For the macro factors, GDP, and inflation rate do not show the significant effects, which is a contrast to the findings from Joon-Ho Hahm (2008) and Abdelaziz et al. (2012). But the payment policy presents the significantly negative influence on non-interest income. It makes sense that when the Chinese government encourages electronic payment and digital payment, the overall payment competition is increasing. More importantly, the significant coefficient of third-party total payment portrays that one percent of third-party total payment will promote the banks' non-interest income with $0.0387 \%$. This implies that although third-party payment platforms distribute banks payment flow, the total electronic payment transactions increase the money velocity. Thus, it leads to a positive spillover effect on banks' non-interest income.

The third-party desktop payment and third-party mobile payment are elaborated in the second column of Table 3 . The results show that significantly, both third-party desktop payment and third-party mobile payment are the determinants of non-interest income of Chinese commercial banks. Differently, non-interest income positively correlated with third-party desktop payment while negatively associated with the third-party mobile payment. This opposite effect embodies the cooperation and competition between China commercial banks and third-party payment providers. Each amount of money for the first time flows into third-party platform must have access to the bank's account. Once there is a transaction, the banks will gain fee income. With the increasing of transactions, banks' non-interest income gets positively promoted. However, the widespread use of smartphone makes mobile payment more attractive. In third-party mobile payment app, it presents many premium functions which serve Chinese people's daily life. When most of the payments process within the mobile payment, a third-party payment platform will form its own ecosystem (Mancy et al., 2017). Besides, third-party payment companies have expanded the payment mode abroad due to the advantage of mobile payment. In order to support the cross-border trade, the Chinese government has relaxed regulatory requirements of cross-border payment services for third-party payment companies. Both Alipay and WeChat pay get into the market of Europe, Japan, Southeast Asia, and other countries. The scope of the mobile payment business includes catering, supermarkets, VAT refunds, department stores, duty-free shops, theme parks, etc. As a result, more transactions in the third-party mobile payment circle tend to reduce the source of commercial banks' non-interest income.

Table 4 shows whether the relationship between third-party payment and commercial banks' non-interest income diverges across the five largest state-owned commercial banks and small-medium commercial banks. By involving the interaction terms approach, we employ random effects panel data techniques to run the regression of Eq. (4). The results in the case of third-party total payment are shown in column 3, while column 4 constitutes the effects from third-party desktop payment and third-party mobile payment. We find that the determinants of non-interest income for both large state-owned banks and small-medium size banks are almost the same but the degree of the effects differ. Large state-owned banks, which can earn more non-interest income, attributes to the economic scale and client resources. Therefore, different ownership or size seems to have a definite effect on non-interest income (Pennathur et al., 2012). Furthermore, there are no such significant differences in the return on assets, overhead ratio and non-performing loan ratio. We also find that macro factors like payment policy and inflation rate facilitate more influences on small-medium banks due to the less stable of financial fundaments. In the perspective of the regulator, as the results note that the payment policy of Barcode Payment Business Norms in 2016 declined bank's non-interest income. It means that bank's non-interest income gets hindered when government encourages the third-party development. Concerning third-party total payment, it is remarkable that the impacts on non-interest income for large state-owned and small-medium banks are divergent. For large state-owned banks, the growth in third-party total payment appears to decline its non-interest income. It indicates large state-owned banks have the disadvantages of meeting individual payment requirements. When young and middle-aged groups have gradually become the main force in the transaction and consumption, they pay more attention to user experience and service. Compared with the large state-owned banks with more complicated organizational structures, the less management hierarchy small-medium banks exert certain advantages in serving small businesses and clients. This is consistent with the empirical evidence on the comparative advantages of large and small banks in the US (Berger \& Black, 2011). Since the small-medium banks have better user experiences, they still can gain the positive marginal non-interest income when third-party total payment has an upswing.

Turning to the third-party desktop payment and third-party mobile payment in column 4 of table 4 , the overall effects on small-medium banks' non-interest income are found similar to the above all banks in column 2. By contrast, large state-owned banks appear to reflect the negative impacts on non-interest income for both third-party desktop payment and third-party mobile payment. As the large state-owned banks act the prudential roles in the Chinese financial market, for a long-term, their businesses more focus on large scale and well-performed enterprises. The individual customers and the small and medium-sized enterprises, who are 
unfulfilled in the bank, start to shift to the third-party payment platforms. Consequently, the booming of third-party desktop payment and third-party mobile payment jointly has been draining the non-interest income of large state-owned banks.

Table 3. Non-interest income and third-party payment

\begin{tabular}{|c|c|c|}
\hline & (1) & (2) \\
\hline VARIABLES & NIIT & NIIT \\
\hline \multirow[t]{2}{*}{ Constant } & $-2.404 * * *$ & $-4.147 * * *$ \\
\hline & $(0.464)$ & $(1.600)$ \\
\hline \multirow[t]{2}{*}{ LNTA } & $0.0464 * * *$ & $0.0544^{*}$ \\
\hline & $(0.0167)$ & $(0.0291)$ \\
\hline \multirow[t]{2}{*}{ LDR } & $0.00241 * * *$ & 0.00161 \\
\hline & $(0.000890)$ & $(0.00152)$ \\
\hline \multirow[t]{2}{*}{ NIM } & $-0.0687 * * *$ & $-0.0533^{*}$ \\
\hline & $(0.0185)$ & $(0.0283)$ \\
\hline \multirow[t]{2}{*}{ ROA } & $0.483 * * *$ & $0.611 * * *$ \\
\hline & $(0.0158)$ & $(0.0246)$ \\
\hline \multirow{2}{*}{ OVHR } & $8.46 \mathrm{e}-05$ & -0.00220 \\
\hline & $(0.00166)$ & $(0.00266)$ \\
\hline \multirow[t]{2}{*}{ NPL } & $0.0881 * * *$ & -0.00366 \\
\hline & $(0.0103)$ & $(0.0391)$ \\
\hline \multirow[t]{2}{*}{ GDP } & -0.00845 & $-0.222 * * *$ \\
\hline & $(0.00650)$ & $(0.0401)$ \\
\hline \multirow[t]{2}{*}{ INFL } & 0.00125 & $0.0434 * * *$ \\
\hline & $(0.00386)$ & $(0.0166)$ \\
\hline \multirow[t]{2}{*}{ POL } & $-0.0514 * * *$ & $-0.0561 * *$ \\
\hline & $(0.0193)$ & $(0.0284)$ \\
\hline \multirow[t]{2}{*}{ LNTPP } & $0.0387 * * *$ & \\
\hline & $(0.00766)$ & \\
\hline \multirow[t]{2}{*}{ LNTPDP } & & $0.206 * * *$ \\
\hline & & $(0.0618)$ \\
\hline \multirow[t]{2}{*}{ LNTPMP } & & $-0.0595^{* * *}$ \\
\hline & & $(0.0163)$ \\
\hline Observations & 587 & 310 \\
\hline Number of id & 16 & 16 \\
\hline
\end{tabular}

Table 4. Non-interest income and third-party payment: differences in bank groups

\begin{tabular}{lcc}
\hline \multirow{2}{*}{ VARIABLES } & $(3)$ & $(4)$ \\
Constant & NIIT & NIIT \\
& $-3.815^{* * *}$ & $-6.727 * * *$ \\
SIZE & $(0.334)$ & $(1.825)$ \\
& -1.467 & 7.415 \\
LNTA & $(1.546)$ & $(4.524)$ \\
& $0.0599^{* * *}$ & $0.114 * * *$ \\
SIZE\#C.LNTA & $(0.00978)$ & $(0.0334)$ \\
& $0.129 * * *$ & 0.00843 \\
LDR & $(0.0477)$ & $(0.116)$ \\
& $0.00218 * *$ & -0.00283 \\
SIZE\#C.LDR & $(0.000956)$ & $(0.00172)$ \\
& $0.00986^{* * *}$ & $0.0103 *$ \\
NIM & $(0.00332)$ & $(0.00614)$ \\
& 0.0222 & -0.0407 \\
SIZE\#C.NIM & $(0.0197)$ & $(0.0280)$ \\
& $-0.151^{* *}$ & -0.160 \\
ROA & $(0.0613)$ & $(0.120)$ \\
& $0.456^{* * * *}$ & $0.622 * * *$ \\
\end{tabular}




\begin{tabular}{|c|c|c|}
\hline SIZE\#C.ROA & $\begin{array}{c}0.0511 \\
(0.0407)\end{array}$ & $\begin{array}{l}-0.0644 \\
(0.0623)\end{array}$ \\
\hline OVHR & $\begin{array}{c}0.00798 * * * \\
(0.00121)\end{array}$ & $\begin{array}{c}0.00254 \\
(0.00263)\end{array}$ \\
\hline SIZE\#C.OVHR & $\begin{array}{l}-0.00363 \\
(0.00410)\end{array}$ & $\begin{array}{c}0.00245 \\
(0.00711)\end{array}$ \\
\hline NPL & $\begin{array}{c}0.105 * * * \\
(0.0137)\end{array}$ & $\begin{array}{l}0.119 * * \\
(0.0472)\end{array}$ \\
\hline SIZE\#C.NPL & $\begin{array}{l}-0.0359 \\
(0.0302)\end{array}$ & $\begin{array}{l}-0.190^{* *} \\
(0.0857)\end{array}$ \\
\hline GDP & $\begin{array}{l}-0.00572 \\
(0.00876)\end{array}$ & $\begin{array}{c}-0.205^{* * *} * \\
(0.0478)\end{array}$ \\
\hline SIZE\#C.GDP & $\begin{array}{l}-0.0147 \\
(0.0159)\end{array}$ & $\begin{array}{c}0.0294 \\
(0.0910)\end{array}$ \\
\hline INFL & $\begin{array}{l}-0.00799 \\
(0.00514)\end{array}$ & $\begin{array}{c}0.0374 * * \\
(0.0185)\end{array}$ \\
\hline SIZE\#C.INFL & $\begin{array}{c}0.0274 * * * \\
(0.00962)\end{array}$ & $\begin{array}{l}-0.0154 \\
(0.0363)\end{array}$ \\
\hline POL & $\begin{array}{c}-0.0499 * * \\
(0.0248)\end{array}$ & $\begin{array}{l}-0.0593^{*} \\
(0.0307)\end{array}$ \\
\hline SIZE\#POL & $\begin{array}{c}0.0423 \\
(0.0563)\end{array}$ & $\begin{array}{c}0.0807 \\
(0.0707)\end{array}$ \\
\hline LNTPP & $\begin{array}{c}0.0603 * * * \\
(0.00755)\end{array}$ & \\
\hline SIZE\#C.LNTPP & $\begin{array}{c}-0.0947 * * * \\
(0.0180)\end{array}$ & \\
\hline LNTPDP & & $\begin{array}{c}0.246 * * * \\
(0.0687)\end{array}$ \\
\hline SIZE\#C.LNTPDP & & $\begin{array}{c}-0.356^{* *} \\
(0.144)\end{array}$ \\
\hline LNTPMP & & $\begin{array}{c}-0.0708 \text { *** } \\
(0.0183)\end{array}$ \\
\hline SIZE\#C.LNTPMP & & $\begin{array}{l}0.0684 * \\
(0.0360)\end{array}$ \\
\hline Observations & 587 & 310 \\
\hline Number of id & 16 & 16 \\
\hline
\end{tabular}

\section{Conclusion and Implication}

\subsection{Summary}

The empirical evidence on the relationship between third-party payment and banks' non-interest income is limited to date whether in developed countries or emerging market economies. Taking China commercial banks as the sample, this paper tries to examine the impacts of third-party payment on non-interest income for the period 2008-2017. We first disentangle the determinants of non-interest income in order to find the control variables. Then the impacts on non-interest income are respectively estimated in terms of third-party total payment, third-party desktop payment, and third-party mobile payment by using random effects panel data techniques. Furthermore, we have explored whether the impacts differ across the large state-owned commercial banks and small-medium commercial banks in China.

Results bespeak that besides banking characteristics, the macro factor like payment policy and third-party payment scales exert strongly impact on non-interest income, likely findings ( but in terms of ATM, card payment, and deregulation) are identified by Abdelaziz et al. (2012) for Tunisian banks. So far Chinese third-party total payment has presented a positive spillover effect on overall commercial banks' non-interest income as third-party payment platform links with online banking interface. It stimulates the whole electronic payment to get promoted (Shujin \& Yinfei, 2016). Similar to the third-party total payment, third-party desktop payment also can push up the non-interest income for banks. On the other hand, it is interesting that third-party mobile payment demonstrates a depression effect on non-interest income. Once the money flows into the third-party mobile payment circle, the functional applications in the mobile phone would attract the payment processed within the third-party payment platforms. 
In addition, the results indicate the impacts on non-interest income differences between the two bank groups (e.g. Pennathur et al., 2012; Sanya \& Wolfe, 2011) For the five largest state-owned commercial banks, the correlation with non-interest income turns out to be extremely negative for entire third-party total payment, desktop payment, and mobile payment. Because of the less concern on the majority of small enterprises and customers' requirements for a long-term, large state-owned commercial banks' non-interest income is subducted, bit by bit, by the third-party payment. However, regarding small-medium commercial banks, only third-party mobile payment exerts the depression effects. In terms of third-party total payment or desktop payment, it enhances non-interest income for small-medium commercial banks.

\subsection{Policy Implications}

Our findings have two important policy implications. First, the reforms of banking sectors need more innovative and incentive efforts, like the concerns from emerging economies in India (Bhaumik, Kutan, \& Majumdar, 2017), Russia and Ukraine (Love \& Rachinsky, 2015), suggesting commercial banks establish modern corporate governance. The reforms with more competition and autonomy contribute the development of banks. Thus, particularly for large state-owned banks in China, set up a standard corporate governance structure and an effective market-based incentive mechanism can help solve the problems of insider control and moral hazard. In this way, with the improvement of user experiences and the service attitudes toward small and medium clients, large state-owned commercial banks can regain more customer base.

Second, supervision of non-interest income activities should be strengthened with respect to the quality and efficiency, as Sun, Wu, Zhu, and Stephenson (2017) mentioned, to provide more resources on non-interest income. In practice, it is necessary for commercial banks to develop the functional mobile banking payment and simplify the payment process for the small amount. With the widespread of the mobile phones, striving for the own mobile payment share is vital to the non-interest income. Moreover, close collaboration with third-party payment platforms is also important. The third-party payment companies grasp more information on the small and medium clients, the collaboration may form the client's credit sharing system to remove the information cost.

For future studies, first, it would be interesting to extensively explore the relationship between the third-party payment and non-interest income based on various bank ownership for different countries. Furthermore, an extension of this paper can estimate the effect of third-party payment on the bank's overall profitability. Understanding how this new trend payment alters bank attains would contribute to yielding countermeasures. Finally, referring to the factoring technique, third-party desktop payment, and mobile payment could be used as the determinants for the development of other financial sectors.

\section{References}

Abdelaziz, H., Helmi, H., \& Mouldi, D. (2012). Modelling Non-interest income at Tunisian Banks. Asian Economic and Financial Review, 2(1), 88-99.

Altunbas, Y., Evans, L., \& Molyneux, P. (2001). Bank Ownership and Efficiency. Journal of Money, Credit, and Banking, 33(4), 926-954. https://doi.org/10.2307/2673929

Atellu, A. R. (2016). Determinants of non-interest income in Kenya's commercial banks. University of Nairobi, 4(December), 98-115.

Beck, T., Demirgüç-kunt, A., \& Maksimovic, V. (2003). Bank Competition and Access to Finance : International Evidence. Journal of Money, Credit, and Banking, 36(3), 627-648. Retrieved from http://www.jstor.org/stable/3838958 Bank Competition

Berger, A. N., \& Black, L. K. (2011). Bank size, lending technologies, and small business finance. Journal of Banking and Finance. https://doi.org/10.1016/j.jbankfin.2010.09.004

Bhaumik, S. K., Kutan, A. M., \& Majumdar, S. (2017). How successful are banking sector reforms in emerging market economies ? Evidence from impact of monetary policy on levels and structures of firm debt in India. The European Journal of Finance, 1-20. https://doi.org/10.1080/1351847X.2017.1391857

Calomiris, C. W. (1998). Universal banking “American-Style." Journal of Institutional and Theoretical Economics, 154(1), 44-57. Retrieved from http://www.jstor.org/stable/40752040

Craigwell, R., \& Maxwell, C. (2006). Non-interest income and financial performance at commercial banks in Barbados: an empirical note. Central Bank of Barbados Working Paper, (18), 241-251.

Davis, E. P., \& Tuori, K. (1998). The Changing Structure of Banks' Income - an Empirical Investigation 1. International Affairs. 
Denecker, O., Gulati, S., \& Niederkorn, M. (2014). The Digital Battle that Banks Must Win. McKinsey \& Company Financial Service. Retrieved from https://www.mckinsey.com/industries/financial-services/our-insights/the-digital-battle-that-banks-must-win

DeYoung, R., \& Hunter, W. C. (2002). Deregulation, the Internet, and the Competitive Viability of Large Banks and Community Banks. The Future of Banking, 312-322.

DeYoung, R., \& Rice, T. N. (2004). Noninterest Income and Financial Performance at U.S. Commercial Banks. Financial Review, 39(1), 101-127. https://doi.org/10.1111/j.0732-8516.2004.00069.x

Diewert, A. W. E., \& Wales, T. J. (1987). Flexible Functional Forms and Global Curvature Conditions. Econometrica, 55(1), 43-68. https://doi.org/10.2307/1911156

Diwanji, A., \& Kannan, V. G. (2017). Banking in the age of disruption. Indian Banks' Association, (February).

Elliott, D. J., \& Yan, K. (2013). The Chinese Financial System: An Introduction and Overview. China Center at Brookings, (July).

Frame, W. S., \& White, L. J. (2004). Empirical Studies of Financial Innovation: Lots of Talk, Little Action? Journal of Economic Literature Review, 42(1), 116-144. https://doi.org/10.1257/002205104773558065

Fuchun, S. (2010). Study on Legal Issues of Third-Party Payment. Jinan: Shangdong University.

Guo, P., \& Shen, Y. (2016). The impact of Internet finance on commercial banks' risk taking: Evidence from China. China Finance and Economic Review, 4(1), 16. https://doi.org/10.1186/s40589-016-0039-6

Hua, S., \& Juanjuan, L. (2017). A brief analysis of the co-opetition relationship between the third party payment institutions and Commercial Banks. Journal of Jilin Business and Technology College, 33(1), 62-66. https://doi.org/10.19520/j.cnki.issn1674-3288.2017.01.012

Joon-Ho, H. (2008). Determinants and Consequences of Non-Interest Income Diversification of Commercial Banks in OECD Countries. Journal of International Economic Studies, 12(1), 3-32. https://doi.org/10.11644/KIEP.JEAI.2008.12.1.178

Junping, F. (2012). The effect of third-party payment on Internet banking business of commercial banks in China. Financial Theory and Practice.

Junshan, D., \& Guoqiang, S. (2011). Determinants of Non-interest Income in China's Commercial Banks: An Non-stationary Panel Cointegration Model. Shanghai Finance, 48-52. Retrieved from https://www.wenkuxiazai.com/doc/0a512b6603d8ce2f01662339-5.html

Karakaya, A., \& Er, B. (2012). Noninterest (Nonprofit) Income and Financial Performance at Turkish Commercial and Participation Banks. International Business Research, 6(1), 106-117. https://doi.org/10.5539/ibr.v6n1p106

Kun, X. (2010). Analysis of the Third-Party Payment Policy: Industry Regulatory Policies and Legal Environment. Saidi Investment and Financing Advisory Center. Retrieved from https://www.wenkuxiazai.com/doc/19e0d8cb0508763231121259.html

Li, L. (2014). Stock \& Forex Trading The Impact of Non-interest Income on the Efficiency of China's Banking Sector. Journal of Stock \& Forex Trading, 3(4). https://doi.org/10.4172/2168-9458.100013

Love, I., \& Rachinsky, A. (2015). Corporate Governance and Bank Performance in Emerging Markets: Evidence from Russia and Ukraine. Emerging Markets Finance and Trade, 51(00), S101-S121. https://doi.org/10.1080/1540496X.2014.998945

M.Wooldrige, J. (2011). Introductory Econometrics. Journal of Contaminant Hydrology, 120-121. https://doi.org/10.1016/j.jconhyd.2010.08.009

Man, S. (2015). An empirical study of the impact of the Internet Finance on the main business and management efficiency of commercial banks. Hangzhou University of Electronic Science and Technology.

Mancy, S., Piyush, M., Tian, L., \& Stanley, T. (2017). The Rise of China FinTech Payment: The Ecosystem Gateway. Equity Research, (August 7), 1-72.

Manning, B. (2015). To bank or not to bank? For non-traditional banking providers, this question has been answered. Retrieved from https://centricdigital.com/blog/digital-transformation/non-traditional-banking-providers/

Markowitz, H. (1959). Portfolio Selection: Efficient Diversification of Investments. New York: John Wiley \& 
Sons: Yale University.

Mostak, A. M. (2017). Asset quality, non-interest income, and bank profitability: Evidence from Indian banks. Economic Modelling, 63(October 2016), 1-14. https://doi.org/10.1016/j.econmod.2017.01.016

Njogu, J. (2014). The Effect of Electronic Banking Profitability of Commercial Banks in Kenya. International Journal of Arts and Commerce, 2(3), 25-29.

Peijun, G. (2014). Internet financial research on the influence of the commercial banks in China. Henan University.

Pelton, W. J. (1960). The determinant of banks' non interest income. American Journal of Public Health and the Nations Health, 50(1), 21. https://doi.org/10.2105/AJPH.50.1.21

Pennathur, A. K., Subrahmanyam, V., \& Vishwasrao, S. (2012). Income diversification and risk: Does ownership matter? An empirical examination of Indian banks. Journal of Banking and Finance, 36(8), 2203-2215. https://doi.org/10.1016/j.jbankfin.2012.03.021

Robleh, A., Barrdear, J., Clews, R., Southgate, J., Ali, R., Barrdear, J., ... Southgate, J. (2014). Innovations in payment technologies and the emergence of digital currencies. Bank of England Quarterly Bulletin, Q3(3), 262-276.

Ross, S. (1976). The Arbitrage Theory of Capital Asset Pricing. Journal of Economic Theory, 13, 341-360. https://doi.org/10.1016/0022-0531(76)90046-6

Sanya, S., \& Wolfe, S. (2011). Can Banks in Emerging Economies Benefit from Revenue Diversification? Journal of Financial Services Research, 40(1), 79-101. https://doi.org/10.1007/s10693-010-0098-z

Shujin, L., \& Yinfei, C. (2016). Spillover Effects of Third Party Payment on Non - interest Income of China 's Listed Banks. Financial Theory and Practice, 70-74.

Shuo, W., \& Ting, L. (2012). Third-party payment impact on the development of commercial banks business. China: Finance Practice.

Smith, R., Staikouras, C., \& Wood, G. (2003). Non-Interest Income and Total Income Stability. Publication Bank of England, 1-40. https://doi.org/10.2139/ssrn.530687

Stiroh, K. J. (2004). Diversification in Banking: Is Noninterest Income the Answer? Journal of Money, Credit, and Banking, 36(5), 853-882. https://doi.org/10.1353/mcb.2004.0076

Sun, L., Wu, S., Zhu, Z., \& Stephenson, A. (2017). Noninterest Income and Performance of Commercial Banking in China. Scientific Programming, 2017. https://doi.org/10.1155/2017/4803840

Tandulwadikar, A. (2015). Digital Payments Strategy for U.S. Retail Banks. Teaneck, New Jersey (U.S.). Retrieved from https://www.cognizant.com/whitepapers/Digital-Payments-Strategy-for-U.S.-Retail-Banks-codex1358.pdf

Thiel, P., \& Levchin, M. (2004). Paypal is Not a Bank. Entrepreneurial Thought Leader Speaker Series: ECorner. Retrieved from http://ecorner.stanford.edu/authorMaterialInfo.html?mid=1036

Thomas, D. (2014). Fintech - The digital (r)evolution in the financial sector. DB Research, (Frankfurt am Main), 39. https://doi.org/ISSN 1612-314X

Wahi, R. (2017). Leading the cashless charge - Evolution of the digital wallet industry in India. Retrieved from https://www2.deloitte.com/content/dam/Deloitte/in/Documents/strategy/in-strategy-leading-the-cashless-ch arge-noexp.pdf

Wenqing, Y. (2015). The Third-party Payment Risk and its Prevention Research. Tianjin University of Commerce, 1-50.

Williams, D. (2007). Pro PayPal E-commerce. https://doi.org/10.1007/978-1-4302-0353-7

Williams, R., \& Dame, N. (2015). Interaction effects and group comparisons (pp. 1-30).

Xu, B., Rixtel, A. V., \& Leuvensteijn, M. V. (2013). Measuring bank competition in China: A comparison of new versus conventional approaches applied to loan markets (pp. 8-9). https://doi.org/10.2139/ssrn.2416742

Yixian, T. (2017). Alipay or WeChat Pay? Who Will Dominate the Internet Mobile Payment Market. E-Commerce, 64-65. https://doi.org/10.14013/j.cnki.scxdh.2017.05.033

Yuhua, Z., \& Xiaodong, C. (2014). An empirical study of the determinants of commercial banks' non-interest 
income in China. Nanjing Audit University, 55-62.

Zhao, T., Casu, B., \& Ferrari, A. (2010). The impact of regulatory reforms on cost structure, ownership and competition in Indian banking. Journal of Banking and Finance, 34(1), 246-254. https://doi.org/10.1016/j.jbankfin.2009.07.022

\section{Appendix}

Appendix 1. Correlation matrix

\begin{tabular}{|c|c|c|c|c|c|c|c|c|c|c|c|}
\hline & NIIT & LNTA & LDR & NIM & ROA & OVHR & NPL & GDP & INFL & POL & LNTPP \\
\hline NIIT & 1 & & & & & & & & & & \\
\hline LNTA & 0.4183 & 1 & & & & & & & & & \\
\hline LDR & 0.2377 & 0.1615 & 1 & & & & & & & & \\
\hline NIM & -0.1835 & -0.2898 & -0.27 & 1 & & & & & & & \\
\hline ROA & 0.6121 & 0.0657 & -0.098 & 0.1871 & 1 & & & & & & \\
\hline OVHR & -0.0819 & -0.3325 & -0.012 & 0.1459 & 0.0575 & 1 & & & & & \\
\hline NPL & 0.2326 & 0.3493 & 0.1085 & -0.059 & -0.062 & -0.074 & 1 & & & & \\
\hline GDP & -0.3419 & -0.3134 & -0.162 & 0.4056 & 0.0636 & 0.3711 & -0.1155 & 1 & & & \\
\hline INFL & -0.1697 & -0.1308 & -0.136 & 0.4025 & 0.05 & 0.0935 & -0.0736 & 0.6705 & 1 & & \\
\hline POL & 0.2166 & 0.2451 & 0.2974 & -0.49 & -0.173 & -0.28 & 0.338 & -0.451 & -0.198 & 1 & \\
\hline LNTPP & 0.4437 & 0.4076 & 0.2597 & -0.5 & -0.037 & -0.438 & 0.1578 & -0.751 & -0.318 & 0.7128 & 1 \\
\hline
\end{tabular}

Appendix 2. Presentation of the sample commercial banks

\begin{tabular}{lcl}
\hline Bank Type & Abbreviation & Full Name \\
\hline \multirow{3}{*}{ Five Largest State-Owned } & ICBC & Industrial and Commercial Bank of China \\
Commercial Bank & ABC & Agricultural Bank of China \\
& BOC & Bank of China \\
& CCB & China Construction Bank \\
& BOCOM & Bank of Communications \\
& PAB & Ping An Bank \\
SPDB & Shanghai Pudong Development Bank \\
Bank & HXB & Huaxia Bank \\
& CMSB & Minsheng Bank \\
& CMBC & China Merchants Bank \\
& CIB & China Industrial Bank \\
& CEB & China Everbright Bank \\
City Commercial Bank & CITIC & China CITIC Bank \\
& BOB & Bank of Beijing \\
\hline
\end{tabular}

Source: Each bank's website.

\section{Copyrights}

Copyright for this article is retained by the author(s), with first publication rights granted to the journal.

This is an open-access article distributed under the terms and conditions of the Creative Commons Attribution license (http://creativecommons.org/licenses/by/4.0/). 